\title{
An Analysis of Employer Requirements of University Graduates
}

\author{
Tünde Tóth-Téglás ${ }^{1}$, Erika Hlédik ${ }^{2}$, Laura Fónadová ${ }^{3}$
}

${ }^{1}$ Óbuda University, Faculty of Business and Management, Tavaszmező utca 17, H-1084 Budapest, Hungary; tothne.teglas.tunde@kgk.uni-obuda.hu

${ }^{2}$ Budapest University of Technology and Economics, Faculty of Economic and Social Sciences, Müegyetem rkp. 3, H-1111 Budapest, Hungary;

hledike@erg.bme.hu

${ }^{3}$ Masaryk University Brno, Faculty of Economics and Administration, Lipová 41a, 60200 Brno, Czech Republic; laura@econ.muni.cz

\begin{abstract}
It is of equally outstanding importance for university graduates and universities alike to learn what requirements workplaces have of graduates and what knowledge and skills they are expected to have. Previous research in Hungary conducted by GVI MKIK and DPR examined employer and higher education graduate views based on the importance of expected competencies. In our research we focused on understanding employer requirements related to the recruitment of graduates. Therefore, we examined the opinions of companies that assumingly had a conscious strategy for employing graduates, and we carried out comprehensive analyses of the findings of comprehensive research. Our research findings reveal that the large companies surveyed assigned primary importance to competencies ensuring present performance; at the same time, the aspect of competencies enabling future performance also emerged as relevant. It was also analysed in our study to what extent the companies surveyed had different requirements of economic and technical graduates. The research furthermore explored with the help of factor analysis in what ways the respective competency requirements were interrelated in the employers' approach. Although our research was conducted among Hungarian companies exclusively, we believe that the findings related to the role of corporate size and field of specialisation may generate conclusions of interest for research carried out in other countries as well.
\end{abstract}

Keywords: workplace requirements; competencies; skill requirements; graduate recruitment process 


\section{An Analysis of Employer Requirements of Graduates}

Understanding what requirements workplaces have of graduates, what knowledge and skills they are expected to have is extremely important for university graduates and universities. Previous research in Hungary conducted by the Institute for Economic and Enterprise Research of the Hungarian Chamber of Commerce and Industry (GVI MKIK) examined employer views based on the importance of expected competencies. One of the main findings of this research was that the demand for higher education graduates in the technical field is more significant than that of graduates in the field of economy. The research showed that the most important competencies appeared to be precision, self-reliance, high work endurance, ability to work in teams and ability to achieve goals. Our research focuses on understanding employer requirements related to the recruitment of graduates. We examined large companies, who have a conscious strategy for employing graduates. As previous research shows there is a difference on the demand side, therefore our aim was to investigate whether there exists a difference also in the competency requirements toward technical and economic higher education graduates.

\subsection{The Higher Education and the World of Work}

Considering the significant changes apparent at the labour market as well as the growing efforts aimed to improve the quality of 'graduate output', understanding labour market requirements has become an important field of study recently.

Szabó and Hámori point out that "at the information age, companies undergo constant transformation and reorganization, their strategy and organization are both flexible." [26] The trends experienced in economic transformation, globalisation, networking, the emergence of new technologies and the changes in consumer habits generate rearrangements in the form and content framework of the world of work as well. Researchers conducting career tracking surveys on graduates in the European region formulate these changes the following way: "While traditional organisations regarded employee care as a basic value, today's workplaces rather expect their employees to have a kind of responsible and selfcaring attitude and make efforts in order that their employees identify with the organisation's values and goals.'[9] In the 'looser' relations of work performance, the emphasis is on task performance, which requires of employees greater independence, fast response, pro-activity and flexible adaptation and significantly "influences the value and contents of the competencies necessary". [13]

In the system of changing environmental factors, companies re-interpret their recruitment and training strategies as well. There is no clear formulation of employer requirements of employees, either, making up for which shortcoming can be regarded as a task which is a key to future success. In the technical 
literature on management, McClelland examines, based on his definition of competency, the relationship between workforce proficiency and employer requirements by researching into the criteria ensuring successful work performance. [18] In a labour market undergoing a transformation as an effect of economic and social changes, the interpretation of success criteria can be interpreted as a relationship dynamically changing both on employers' and employees' sides. [16] Employers constantly look for the personal abilities and knowledge that ensure the implementation of their strategic plans both in the short and long run. [4] On the other hand, the 'competency set' of an organisation, which determines the company's performance, is also influenced by the employees' proficiency, motivations and competency mismatches. [1] Accordingly, the practice of competency management is based on the broad-scale and regular communication of the company's management, HR specialists and employees, in the course of which the specification of recruitment criteria and training goals and the elaboration of employee assessment factors are based on the formulation of current and future employer competency requirements that support serving the strategic goals.

Some employees find it easier, others more difficult to adapt to the requirements that are new or under transition. "Technological change generates a conflict between the demand for and the supply of competencies." [9] The salary differences emerging between high and low skilled employees draw attention to the fact that "the demand for high skilled workforce has emerged in the economy. Inequalities in remuneration are rooted in the fact that the supply side is unable to keep pace with the needs of the demand side." [9] Cedefop's European skills and jobs (ESJ) survey pointed out that "skill mismatch" might be one of the reasons why employers are unable to fill vacancies, despite the high level of unemployment in certain areas. [3] Skill mismatch is "the gap between the skills required on the job and those possessed by individuals". [3] This gap may be caused partly because of the increase in company expectations or changes in job requirements observed in the labour market. [10] On the other hand, the gap between required and possessed competencies may have its roots in imperfect information about job opportunities, but also in individual educational and skill shortage or underlying problems of higher education. [17] The role of higher educational institutions is essential, as it is shown in research conducted by Hungarian institutions, there is a gap between theoretical oriented practice of universities and the practice oriented requirements of the labour market. [8]

This process generates new tasks for institutions preparing graduates. Based on the educational implications of EU 2020 strategy [6], the initiative "Agenda for new skills and jobs" aims to increase the match between the labour market supply and demand side by supporting life-long learning and skills development. [19] Interpreting education as a value creating process, its task is to 'deliver' the competencies required by society and the labour market. "It is increasingly through this that the content requirements and achievements of studies are 
monitored and developed in higher education." [15] The concept of competency was used in pedagogy in a different interpretation before (discussed in Tóthné Téglás [31]), but there is a shift from this interpretation of competence towards interpretation used management practice in order to understand better the expectations of labour market. In this context the process of learning is approached from the direction of the achievements attained [11] [29] [30] [12], and various learning and carrier building opportunities are available for students. [14] [21] In such an output approach, institutions make efforts to learn about labour market requirements following a pull strategy and aim to train graduates employable in the labour market. [2]

Correspondence between the level and field of studies and the requirements of a position can be examined by identifying under and overqualified areas, assessing learning skills and measuring to what extent students are prepared for future tasks as well as the performance of indeterminable, innovative tasks. [28] From the beginning of the 2000's the international graduate career tracking system research (CHEERS, REFLEX, HEGESCO) focused on the identification of general competencies essential in the rapidly changing environment and the contribution of higher education. In those research projects the role of competencies, too, was examined among factors determining professional success. Even though no factors were found to have outstanding effects, it could be concluded as regards to competencies, that they primarily influenced the subjective elements of work. [22] In the international graduate career tracking system research, the examination of workplace requirements measures the necessary and the acquired levels of competency based on fresh graduate's opinions several years after their entry to work. As the further development of previous research, the Tuning project carried out by cooperating European universities "initiated a series of consultations at the European level with employers, higher education graduates and university lecturers participating in order to determine the competencies considered to be of key importance for a higher education degree." [16] The main finding of this research was that there were distinctive differences between graduate's and employer's responses although the correlation between the competencies considered most important was high $(r=0.9)$.

The role of competency assessment in higher education research is to implement education better adjusted to labour market needs. Differences in the interpretation of competency in pedagogy and management made the compilation of competency lists applied in competency research difficult. As an effect of employer requirements, both cognitive and non-cognitive elements determining success at work have been included in the range of competencies assessed in the research. [16] A uniform competency model generally accepted in the respective fields is not available either in higher education research or in management; several approaches can be applied. [31] [23] The criteria for outstanding performance in a given position can be investigated by examining the characteristic features of the people filling the positions or by considering the 
skills and knowledge required to fulfil the tasks. These correspond to what are referred to as the income and outcome approaches to competencies. [32] [27] The competency models can differ in what components they consider important. Applying the income approach, American models emphasise personal and social skills, while in the British approach using the outcome approach of competencies, the role of functional skills is underlined. The models worked out in the course of developing German technical training complemented personal and social competencies by professional and methodological/learning competences. [32] Accordingly, various competency lists can be found in the research that makes it more difficult to compare results.

\subsection{Hungarian Research Findings}

Labour market requirements of graduates can be examined on the basis of employer views or the experience of fresh graduate entrants. In what follows, we summarize the findings of research conducted in Hungary. The Institute for Economic and Enterprise Research of the Hungarian Chamber of Commerce and Industry (GVI MKIK) set out to survey the current situation and changes of the demand side, i.e. the labour market, within the framework of which they have made several surveys of the characteristics of the current and future employment of graduates among Hungarian enterprises since 2005. Research conducted by GVI MKIK in 2008 and 2011 (herein after GVI 2008 and GVI 2011) examined employer views also on the basis of experience from recruitment process and the importance of expected competencies. [33]

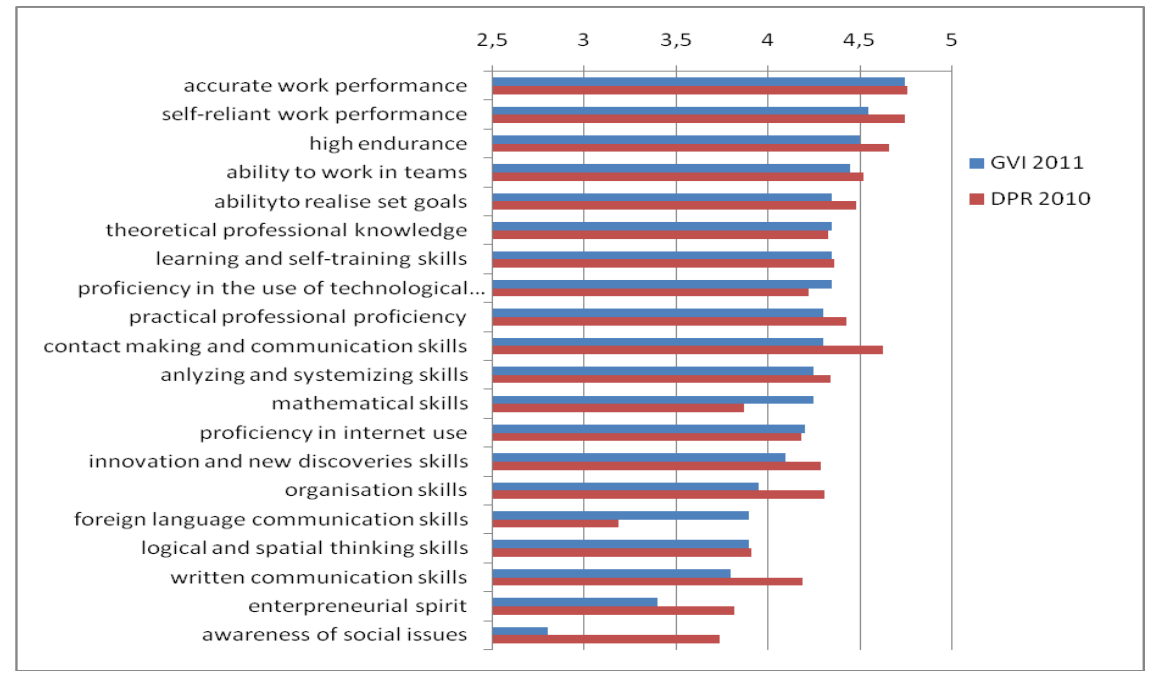

Figure 1

Competency requirements as perceived by graduates with a higher education degree and employers' actual competency requirements based on research by GVI 2011 and DPR2010 [16] [33] 
Considering research focusing on issues related to the quality of fresh graduate output, national graduate career tracking system research (hereinafter DPR) conducted by Educatio Social Services Nonprofit Ltd. analyses the opinion and the workplace experience of persons who graduated a few years ago and have already entered the labour market. In their research programme, they primarily examine the roles of socio-demographic, motivational, institutional and fieldspecific features in the process of transition from higher education to the world of labour. Building on experience from the international Tuning-project, the comprehensive graduate career tracking system research conducted in Hungary in 2010 (hereinafter DPR 2010) complemented the study of workplace adjustment, in addition to examining qualifications, by examining the competencies required for the scopes of work, with the aim to measure adjustment in a more complex way. [16] Thus, the DPR 2010 research surveyed the requirements perceived by employees on the basis of the workplace experience of graduates of various fields, ranking the importance of the respective competencies as experienced in their work. In the next section we summarize the finding of this research (DPR 2010, GVI 2011) because since then this research has not measured competencies.

The DPR 2010 domestic research conducted with a high number of subjects $(\mathrm{N}=4511)$, surveying the opinions of graduates who had graduated three years before and had already entered the labour market, and the employer surveys performed by GVI MKIK in $2008(\mathrm{~N}=3200)$ and repeated in $2011(\mathrm{~N}=1313)$ give an opportunity for the comparison of the views of the two sides. [16] [33]

The research findings recorded by GVI in 2011 revealed a radically different order of preferences compared to three years before. Examining the values on the same scale as the one used for the categories in DPR 2010, research participants evaluated the importance of competencies along a much wider span than before (the lowest mean value being 2.8 and the highest 4.75 ), which may indicate that they perceived preferences more precisely. Requirements having become clearer is also reflected by the fact that the corporate preferences shown in 2011 reflected a much similar picture as the views of graduates interviewed in 2010 (DPR 2010). When arranging data into quartiles, the most important competencies appear to be precision, self-reliance, high work endurance, ability to work in teams and ability to achieve goals (Figure 1). The second quartile includes competencies related to professional proficiency, practical experience and learning. Interestingly, innovation skills, entrepreneurial spirit and foreign language skills, which could be key factors amidst the changing economic requirements to future success, were ranked among less important competencies. Considering this it can be assumed that the emergence of clear requirements can in fact be attributed to a temporary, but strong appearance of self-sustaining functions related to the economic crisis. It is with language skills that the opinions of employers and graduates differ to the greatest extent; graduates regard it even less decisive for their work than employers. At the same time, awareness of social issues, entrepreneurial spirit and written communication skills were competencies regarded less important by 
employers, while graduates ranked these requirements higher than the actual requirements placed upon them.

In the DPR 2010 research, the competency categories of the Tuning project were applied for the sake of comparability. On the basis of a person-oriented income approach, the thus applied categories formulate basic skills deducible from the original arrangement of the competencies. In the course of the analysis examining the co-occurrences of young graduates' responses revealed by factor analysis, the 20 competencies used in the research, displaying a relatively clear structure, were arranged in four dimensions accounting for $49 \%$ of the variance on the whole. [16] Abilities and skills related to self-reliant work performance and contact maintenance were assigned in the Cooperation factor. The second, Instrumentalcognitive factor includes the use of technical devices and basic cognitive competences (writing, reading, computation) and, even though assigned medium weight, the knowledge of foreign languages was also put into this category according to respondents' opinions. Entrepreneurial spirit and openness towards innovation were categorised under the third factor, Social initiatives. The fourth factor of Professionalism includes theoretical and practical professional proficiency and the ability to develop these.

As a way of summary, the domestic DPR 2010 research outlined above explored the competency requirements perceived by graduates, while in the analyses performed by GVI, the ranking of importance of requirements placed upon fresh graduates was made on the basis of corporate opinions. In our own research, we also examined corporate requirements of graduates in the case of technical and economic employees. At the time the data were recorded for our research, the research findings of GVI 2011 were not yet known so we were unable to use the experience; therefore, we used the research findings retrospectively for our comparative analysis.

\section{Corporate Survey}

\subsection{Objective and Methodology of the Survey}

In our survey we examined the opinion of the demand side through a relatively narrow corporate group, also narrowing the field included in the survey. We examined the workplace requirements of primarily large companies actively recruiting fresh graduates from technical and economic fields. Our research findings created opportunity for examining new aspects: the differences according to corporate size and fields of specialisation. We focused on the HR representatives who participate in job fairs, because we believe that they have clear ideas about requirements for fresh graduates to meet, and have the appropriate insight into corporate requirements of graduates. It can be assumed 
that companies exhibiting at a job fair have a conscious concept on the recruitment of graduates, have requirements in place and await fresh graduates with adequate recruitment and training programmes. For this reason, we believe that we managed to reach an important target group from the point of view of our research since we were able to address companies actively looking for graduates and explore their views.

We narrowed down our focus to two segments of graduates namely technical and economic fields, because according to KSH in 2012 most of the tertiary graduates belong in these two segments (38\%). They reasonably face and in future will have to face more competition while seeking for job. Our analysis of the arrangement of competency requirements delivered findings that prove interesting especially in comparison with the findings of the DPR 2010 research.

Our primary research was conducted at the Faculty of Business and Management of Óbuda University (hereinafter OE). The aim of our research was to explore workplace requirements of economic and technical graduates. In the OE survey, we interviewed the HR representatives of companies at 4 job fairs held in the Central Hungarian region (in Kecskemét, Gödöllő and 2 in Budapest: organised at Óbuda University and by HVG Publisher respectively) with the help of interviewers ${ }^{1}$. Considering that there was convenient sampling, our findings cannot be regarded as representative considering company size or ownership structure in Hungary. On the other hand, we believe we managed to reach an important segment in term of our research (HR representatives participating in job fairs, who have clear requirements for fresh graduates).

In our research we sought responses to the following questions:

1) What requirements do companies actively looking for graduates have of graduates? What are competencies of outstanding and of lesser importance?

2) How are competency requirements arranged in the respondents' ways of thinking?

3) Do corporate requirements of technical and economic graduates differ?

In the first part of the questionnaire, we asked about the characteristics of the respondents' companies and the recruitment procedures applied by them. Based on the findings of the GVI 2011 research, companies attribute several advantages to employing graduates. According to two thirds of the companies participating in their research, young people bring new spirit and new ideas to the company, they are easy to shape, they become most valuable work force in the medium run already and take on more workload. [32] We therefore regarded it as important to first of all examine for what positions the companies exhibiting at job fairs look

1 Students Enikő Kardos and Lajos Barcza performed the interviews within the framework of their activities in the Scientific Student Association. 
for graduates. We also wanted to know to what extent companies are conscious in shaping their requirements in the recruitment process of graduates and whether they used competency-based recruitment tools. According to research conducted in Northern Hungary, the practice of large multinational companies is characterised by conscious and planned training activity. [20] Considering that corporate training and recruitment are systems closely built upon one another, it could be assumed that the organisations of respondents, most of whom belonged to corporate circles, used consciously designed and shaped procedures for determining recruitment criteria and implementing the recruitment procedure.

Based on the list of competencies presented in the second part of the questionnaire, we asked respondents to mark the importance of competencies expected with reference to the positions concerned on a 7 point Likert scale. The competencies used in the research were formulated according to the categories generally used in education. We designed our competency list based on Sonntag \& Schaffer-Rauser's model [7]. This competency model includes professional, methodological, social and personal skills as well, so, similar to DPR research, it examines cognitive and non-cognitive competencies alike. Based on the competency categories of this model, we finalised the list by consulting researcher and experts of this topic at the university. We add new competencies compared to the competency lists used in earlier research, which we judged could be important in scopes of work performed by higher education graduates. These included among others ethical behaviour and demand for multidisciplinary knowledge.

In the questionnaire we asked respondents to evaluate separately requirements towards graduates having technical and economic qualifications in order to understand the differences in the competencies required. Our original sample of respondents was 98 companies, but owing to deficiencies in filling in some of the questionnaires, the final number of questionnaires that could be processed was 88 . Considering that respondents could make the competency evaluation with reference to the positions to fill, we were able to use 111 work scope evaluations when analysing the competency evaluations, of which 73 referred to positions requiring technical and 38 requiring economic qualifications. The data were analysed with the help of the SPSS 19 programme package.

\subsection{Characteristics of the Companies Participating in the Survey}

We aimed to address companies actively looking for graduates. $78 \%$ of the companies participating in the research liked to employ graduates, out of which $48 \%$ said that they very much liked to recruit graduates. Companies do not only look for trainees at job fairs; $92 \%$ of the responding corporations employed graduates full-time. At the same time, internship and trainee programmes are popular as well: $53 \%$ of the companies interviewed advertised such positions. These positions offered excellent opportunities to graduates and assumed, on the 
companies' part, a conscious and planned workforce asset training programme by which the company prepared for its future workforce demand by recruiting talented young people. $18 \%$ of the respondents looked for graduates for temporary employment, which could be either genuine temporary demand or often served as a trial period in the course of which the workplace management were able to survey the young people's abilities and their attitude to work in the practice.

As regards their fields of activity, the companies in the sample having a seat in Hungary operate in a wide range of fields. As regards size, it was primarily large companies that were included in the sample, which can partly be explained by their presence at the job fair. In $83 \%$ of the companies interviewed, the number of employees was above 250 people; in the case of 14\%, it was between 50-250 people and in the case of $3 \%$ it was under 50. Considering ownership relations, $75 \%$ of the sample were foreign-owned, $9 \%$ were of mixed ownership and $15 \%$ Hungarian-owned.

The sample included companies of larger sizes the majority of which were foreign owned or had mixed ownership, which assumingly had a relatively conscious recruitment strategy. Findings only partly confirmed the latter assumption. The recruitment practice of the companies interviewed is based on a competencybased concept only in the case of less than half of the companies in the sample. In the practice of only $38 \%$ of the companies interviewed do they use uniform competency profiles for scopes of work or the company as a whole; $55 \%$ of them conduct competency-based interviews and only $31 \%$ recruit graduate employees by using an Assessment Centre. In the recruitment of graduates, the most decisive recruitment tool applied is a job interview with the manager $(84 \%) ; 58 \%$ of the companies have applicants also fill in an aptitude test, while only $8 \%$ of the companies require that written technical papers be submitted.

\section{The Importance of Required Competencies}

The HR representatives participating in the survey evaluated the importance of the competencies listed with reference to the advertised positions on a 7 point Likert scale. Table 1 shows the competencies in order of their importance perceived by companies actively looking for graduates. Mean scores range between values of 6.39 and 3.47. (Table 1) In our analysis, we first present the results calculated for the total sample, followed by the presentation of the differences between the two fields of study.

The most important competency requirement among participating HR representatives was problem-solving skill $(\mathrm{M}=6.39, \mathrm{SD}=0.755)$. This is followed by self-reliant and precise work performance $(\mathrm{M}=6.38, \mathrm{SD}=0.825)$, cooperation with others $(\mathrm{M}=6.23, \mathrm{SD}=0.835)$, information acquisition and processing skills $(\mathrm{M}=6.06, \mathrm{SD}=0.920)$ and foreign language proficiency $(\mathrm{M}=6.01, \mathrm{SD}=1.404)$, and 
finally, ethical behaviour $(\mathrm{M}=0.6, \mathrm{SD}=1.206)$. Competencies ranked in the first quartile according to importance serve current performance primarily. Companies actively looking for graduates expressed that most important competency they expected from graduates were self-reliant and efficient work performance 'from the very first moment'. These competencies closely related to work performance that determines the success of their recruitment.

The further competencies in the order of importance judged as important by companies, i.e. commitment to further continuous learning, openness to changes, flexibility, self-confidence and inner motivation, workload tolerance and endurance, and oral communication skills can still be categorised as competencies fostering independent work performance. However, this second quartile already includes competencies that may serve future work performance. These are: creativity, openness and flexibility, and information acquisition and processing skills and the ability to manage changes. These competencies were less highly ranked in previous research and were often in the less important part of the list. This may suggest that in the sample including large companies primarily, companies are further-sighted and their preferences include, in addition to the criteria for present success, success factors for the future as well. Therefore, they formulate much more complex requirements of higher education graduates.

According to the findings of the survey, companies ranked theoretical and practical professional proficiency in the third quartile. This result could suggest that there is less emphasis on professional proficiencies, but in fact these requirements, too, had very high scores. Theoretical knowledge was ranked 5.65 and applied practical proficiency 5.28 on the 7 point scale. Thus, in fact results do not reflect a 'depreciation' of professional proficiency but a growing role of soft skills related to other work performance. In complex scopes of work requiring a higher education degree, successful work performance is not guaranteed by high professional proficiency in itself. Without personal and social competencies, professional tasks cannot be successfully accomplished.

Among less important competencies, but still in the third quartile we also find IT skills, tolerance, strategic thinking as well as decision making and risk taking skills. The companies interviewed regard management and leadership skills and multidisciplinary knowledge as the least important among the requirements placed on graduates. The competencies ranked less important are primarily used in the performance of duties related to managerial duties, which is proven by the other competencies at the bottom of the ranking whose ranking is lower even in absolute terms, like negotiation techniques, high-level writing skills and influencing and supervisory skills. On the basis of the evaluation monotony tolerance does not seem to be relevant for the recruitment of graduates, either. 
Table 1

The importance of respective competencies based on the $\mathrm{OE}$ research

(Scale of 7; 1- not important at all, 7 - extremely important; mean, standard deviation, $\mathrm{N}=111$ )

Source: authors' calculations

\begin{tabular}{|c|c|c|c|c|c|c|}
\hline & \multicolumn{2}{|c|}{$\begin{array}{l}\text { economic } \\
\text { qualification }\end{array}$} & \multicolumn{2}{|c|}{$\begin{array}{l}\text { technical } \\
\text { qualification }\end{array}$} & \multicolumn{2}{|c|}{ Total } \\
\hline & $\mathrm{M}$ & SD & $M$ & SD & $M$ & SD \\
\hline Problem solving skills & 6,38 &, 721 & 6,40 & ,777 & 6,39 & ,755 \\
\hline $\begin{array}{l}\text { Self-reliant, precise work } \\
\text { performance; initiative approach }\end{array}$ & 6,65 & , 484 & 6,24 & ,927 & 6,38 & ,825 \\
\hline $\begin{array}{l}\text { Cooperation with others, working in } \\
\text { group }\end{array}$ & 6,50 & 655 & 6,10 &, 885 & 6,23 &, 835 \\
\hline $\begin{array}{l}\text { Information acquisition and } \\
\text { processing skills }\end{array}$ & 6,36 & ,798 & 5,92 & ,946 & 6,06 & ,920 \\
\hline $\begin{array}{l}\text { High proficiency in at least one } \\
\text { foreign language }\end{array}$ & 6,14 & 1,475 & 5,95 & 1,373 & 6,01 & 1,404 \\
\hline Commitment to ethical action & 6,22 & 1,134 & 5,89 & 1,234 & 6,00 & 1,206 \\
\hline $\begin{array}{l}\text { Commitment to further continuous } \\
\text { learning }\end{array}$ & 5,81 & 1,175 & 6,08 & 1,057 & 5,99 & 1,100 \\
\hline Openness to changes, flexibility & 6,16 & ,764 & 5,89 & 1,061 & 5,98 & ,977 \\
\hline $\begin{array}{l}\text { Self-confidence and inner } \\
\text { motivation }\end{array}$ & 6,14 & 1,110 & 5,88 & 1,079 & 5,96 & 1,091 \\
\hline Responsibility taking skills & 6,08 & 1,064 & 5,88 & 1,260 & 5,95 & 1,197 \\
\hline Creative thinking skills & 5,68 & 1,292 & 6,03 & 1,093 & 5,91 & 1,170 \\
\hline Workload tolerance and endurance & 6,05 & ,998 & 5,81 & 1,002 & 5,89 & 1,003 \\
\hline Oral communication skills & 6,35 &, 824 & 5,50 & 1,252 & 5,78 & 1,194 \\
\hline Ability of manage conflict & 5,97 & ,910 & 5,68 & 1,035 & 5,77 & 1,001 \\
\hline Ability of manage changes & 5,78 & ,976 & 5,63 & 1,173 & 5,68 & 1,108 \\
\hline $\begin{array}{l}\text { High professional proficiency, up- } \\
\text { to-date theoretical knowledge }\end{array}$ & 5,14 & 1,291 & 5,90 & 1,157 & 5,65 & 1,250 \\
\hline Proficiency in the use of modern IT & 5,20 & 1,389 & 5,48 & 1,237 & 5,39 & 1,289 \\
\hline $\begin{array}{l}\text { Awareness of the practical methods } \\
\text { applied }\end{array}$ & 4,89 & 1,326 & 5,47 & 1,311 & 5,28 & 1,338 \\
\hline Tolerance of other (various) views & 5,44 & 1,340 & 5,08 & 1,372 & 5,20 & 1,367 \\
\hline Decision-making skills & 5,32 & 1,292 & 4,99 & 1,494 & 5,10 & 1,433 \\
\hline Strategic thinking skills & 4,70 & 1,288 & 4,89 & 1,309 & 4,83 & 1,299 \\
\hline Risk-taking skills & 4,78 & 1,377 & 4,68 & 1,433 & 4,72 & 1,409 \\
\hline Presentation skills & 5,00 & 1,309 & 4,54 & 1,426 & 4,69 & 1,400 \\
\hline High-level writing skills & 5,11 & 1,308 & 4,41 & 1,489 & 4,65 & 1,463 \\
\hline $\begin{array}{l}\text { Application of learning techniques } \\
\text { and strategies }\end{array}$ & 4,64 & 1,376 & 4,65 & 1,385 & 4,64 & 1,375 \\
\hline Tolerance of monotony & 4,86 & 1,549 & 4,46 & 1,357 & 4,59 & 1,429 \\
\hline $\begin{array}{l}\text { Application of negotiation } \\
\text { techniques }\end{array}$ & 4,69 & 1,618 & 4,11 & 1,505 & 4,30 & 1,561 \\
\hline
\end{tabular}




\begin{tabular}{|l|c|c|c|c|c|c|}
$\begin{array}{l}\text { Ability to influence and supervise } \\
\text { others }\end{array}$ & 4,22 & 1,530 & 3,75 & 1,489 & 3,91 & 1,512 \\
$\begin{array}{l}\text { Management and leadership skills } \\
\begin{array}{l}\text { Proficiency in several fields of } \\
\text { science }\end{array}\end{array}$ & 4,03 & 1,647 & 3,44 & 1,500 & 3,64 & 1,568 \\
\end{tabular}

Considering the findings, there are no clearly formulated competency requirements related to learning. The application of learning techniques and strategies is ranked $25^{\text {th }}$ in the list, which is even more surprising given the fact that commitment to continuous learning was ranked $7^{\text {th }}$ in the order of preferences. As regards competencies newly included in our competency list, ethical behaviour had a high ranking, while the survey did not confirm any demand for multidisciplinary knowledge.

On the basis of the research findings, there seem to emerge some remarkable differences between competency requirements for technical and economic positions. As the highlighted figures of Table 1 show there are higher requirements as regard to oral and written communication as well as management skills for economic positions as compared to technical jobs. At the same time, technical fields pose higher requirements in professional and practical proficiency and creative thinking. Self-reliance, endurance, cooperation skills, information management, decision making and negotiation skills were ranked somewhat higher for economic positions. Strategic thinking and IT skills, on the other hand, proved somewhat more important for technical fields. Learning competences have about the same place in the ranking of the two fields, while the mean values are a little higher for technical graduates.

\section{Structure of Competencies}

The 30 items of competencies were subjected to principal component analysis (PCA) using SPSS. Prior to performing PCA the suitability of data for factor analysis was assessed. The Kaiser-Meyer-Olkin (KMO) measure of sampling adequacy value was 0.73 , and the Barlett's test of Sphericity reached statistical significance, supporting the factorability of the correlation matrix. Using Kraiser's criterion principal component analysis revealed the presence of seven components with eigenvalues exceeding 1 , explaining $67 \%$ of total variance. To aid in the interpretation of these components, Varimax rotation was performed. The rotated solution is presented in Table 2 . 
Table 2

Competency factors based on the $\mathrm{OE}$ research

Source: drafted by the authors

\begin{tabular}{|c|c|c|}
\hline $\begin{array}{l}\text { Competency } \\
\text { components }\end{array}$ & Competencies & Factor weight \\
\hline \multirow{7}{*}{$\begin{array}{l}\text { Adaptation } \\
\text { competencies }\end{array}$} & Workload tolerance, endurance & .781 \\
\hline & Commitment to ethical action & .765 \\
\hline & Responsibility taking skills & .749 \\
\hline & Ability of manage conflict & .709 \\
\hline & Risk taking skills & .678 \\
\hline & Self-confidence, inner motivation & .663 \\
\hline & Ability of manage changes & .573 \\
\hline \multirow{7}{*}{$\begin{array}{l}\text { Communication } \\
\text { skills }\end{array}$} & Application of negotiation techniques & .811 \\
\hline & Presentation skills & .775 \\
\hline & Management and leadership skills & .760 \\
\hline & Ability to influence and supervise others & .605 \\
\hline & Oral communication skills & .538 \\
\hline & Proficiency in several fields of science & .534 \\
\hline & High-level writing skills & .518 \\
\hline \multirow[t]{5}{*}{ Openness } & Openness to changes, flexibility & .690 \\
\hline & Creative thinking skills & .687 \\
\hline & Commitment to further continuous learning & .670 \\
\hline & Tolerance of other (various) views & .636 \\
\hline & $\begin{array}{l}\text { Application of learning techniques and } \\
\text { strategies }\end{array}$ & .557 \\
\hline \multirow{4}{*}{$\begin{array}{l}\text { Problem and } \\
\text { task solving }\end{array}$} & Use of modern IT & .704 \\
\hline & Problem solving skills & .689 \\
\hline & Information acquisition and processing skills & .656 \\
\hline & $\begin{array}{l}\text { Self-reliant, precise work performance; } \\
\text { initiative approach }\end{array}$ & .493 \\
\hline \multirow{2}{*}{$\begin{array}{l}\text { Professional } \\
\text { proficiency }\end{array}$} & Awareness of the practical methods applied & .825 \\
\hline & $\begin{array}{l}\text { High professional proficiency, up-to-date } \\
\text { technical knowledge }\end{array}$ & .806 \\
\hline \multirow[t]{3}{*}{ Cooperation } & $\begin{array}{l}\text { High proficiency in at least one foreign } \\
\text { language }\end{array}$ & .849 \\
\hline & Tolerance of monotony & .661 \\
\hline & Cooperation with others, working in group & .520 \\
\hline \multirow{2}{*}{$\begin{array}{l}\text { Decision- } \\
\text { making }\end{array}$} & Decision-making skills & .716 \\
\hline & Strategic thinking skills & .475 \\
\hline
\end{tabular}

The first component, which can be regarded as the competency group of Adaptation competencies includes workload tolerance, ethical behaviour, responsibility taking, conflict management, risk taking, self-confidence and ability 
to manage changes. This component could be interpreted as a requirement of ability to adapt to a rapidly changing environment, and to integrate into the organization. The second component consists of competencies that represent various Communication skills, since this component includes items as negotiation techniques, presentation skills, management and leadership skills, ability to influence and supervise others, oral and written communication skills and proficiency in several fields of science. Openness to change, flexibility, tolerance, creative thinking and learning competences are placed in the third component, which we termed the component of Openness. The fourth component includes competencies determining Problem-solving ability, like problem-solving skills, information management skills, use of IT, self-reliant and precise work performance and initiative approach. The fifth component is made up by just two competencies, high-level professional proficiency and awareness of the practical methods applied. We called this component Professional proficiency. Unlike in different research findings, cooperation with others was ranked only to the sixth component. Although proficiency in foreign languages and tolerance of monotony "fit" this category to a lesser extent, considering the importance of social competency we termed this factor Cooperation. The seventh component can be described as a requirement for Decision-making competencies, and this is associated with the competencies of decision-making skills and strategic thinking.

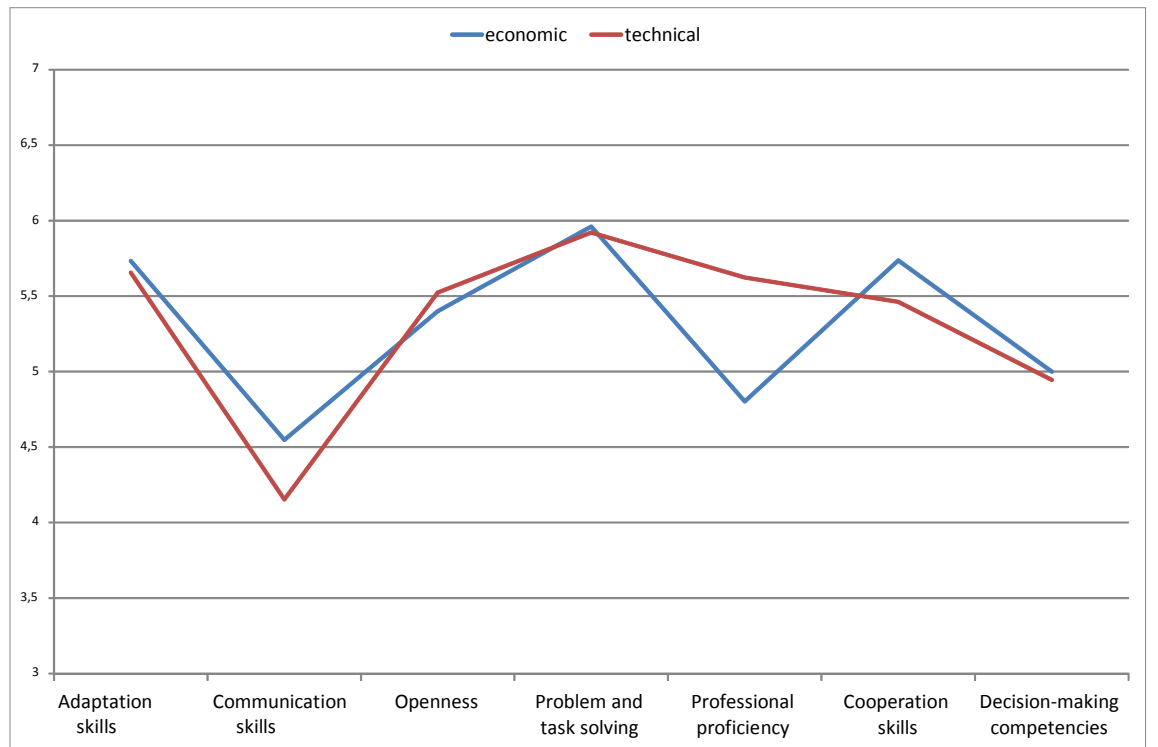

Figure 2

Means of indices calculated on the basis of the competency factors in the case of economic and technical graduates, based on the OE research 
In the interpretation of cooperation and learning competences we attained interesting new findings compared to previous research. Cooperation and competencies serving self-reliant work performance are usually interpreted as competences built upon one another in groupings, while in our research the HR representatives of the companies interviewed interpreted cooperation separately from competencies determining individual performance. In our sample, learning competences were clearly arranged in the factor of openness and creativity. This may imply that the companies interviewed think in broader terms about learning competences, which may also refer to the method and content of learning. Learning is thus evaluated as a tool to future adaptation especially by the HR representatives of large companies, in contrast to previous research findings where respondents clearly relate learning to professional competencies.

In order to analyse the differences related to positions requiring technical or economic qualifications, we created new variables (competency factor index) by adding scores of items belonging to a given factor and then we calculated an average. The averages of the competency factor indexes are shown in Figure 2. The ANOVA analysis and the nonparametric test (Mann-Whitney $U$ test) performed revealed that in the case of five factors out of seven the expectations towards graduates were very similar; however, there were clear differences as regards leadership skills $(\mathrm{F}=5.610 ; \mathrm{p}=0.02)$ and professional proficiency $(\mathrm{F}=6.542$; $\mathrm{p}=0.012$ ). In the companies' evaluations, the competencies of communication skills proved more important for economic graduates, while professional proficiency was judged more important in the technical field ${ }^{2}$.

Although general requirements and those related to specific scopes of work are difficult to separate, the differences apparent from the findings may also suggest that thinking in terms of general competencies is reflected in different ways in the case of different professions. For an employee starting an engineer's career, professional proficiency and awareness of practical solutions are already essential at the time of entry so that he can join the work of an engineers' team; this basic proficiency to be acquired at school is even necessary for the self-reliant performance of subtasks. In the case of scopes of work requiring economic qualifications it holds true certainly in the beginning and probably later as well that the role of soft skills is more decisive for the successful performance of professional tasks. Economic graduates are more likely to perform tasks requiring complex communication skills (negotiation, presentation, coordination, organization, supervision) and operational management tasks later on than their colleagues working in technical fields. We would have found it interesting to explore the differences in learning competences as well, but in our sample there proved to be no difference between the two fields as regards this competence.

2 The variance analysis and nonparametric test performed on the original factor variables confirmed the same correlation. 


\section{Conclusions}

In our analysis we examined the requirements placed on graduates in the world of work. Building on the data of secondary research, we examined workplace adjustment in the course of the transition from school to work by presenting our own research findings. We first compared the findings of research conducted in the two most important target groups affected: of GVI 2011 examining the requirements of the employer side and of DPR 2010 exploring the competency requirements perceived by graduates. In our research, we primarily examined corporate requirements placed on technical and economic graduates. In our sample we addressed companies actively looking for graduates, assuming that these companies had conscious requirements of entrants to the labour market.

Our results show that competencies serving present performance proved the most important for companies, which implies that self-reliant and efficient work performance is expected of graduates 'from the first moment'. In the second quartile of competencies we found different results compared to the GVI research. In the GVI corporate sample of mixed composition, professional competencies were listed in this quartile, while in our research based on a sample of primarily large companies, competencies relevant for the future. However, in line with previous research our survey confirmed that successful work performance is not guaranteed by high professional proficiency in itself; without personal or social competencies, professional tasks cannot be successfully performed. Examining the co-occurrence of competencies based on employer responses in our research it can be concluded that in the way of thinking of corporate representatives, requirements are arranged very differently from the way the opinions of graduates participating in the DPR2010 research were arranged. In the examination of differences between the requirements of technical and economic graduates, it was the comparison of group means per factor that generated interesting findings.

Similar results bring knowledge within a Czech context. ${ }^{3}$ Research by the National Institute of Education of the CR focused on the requirements and expectations of employers. In the responses of employers operating in the tertiary sectors lightly prevailed answers preferring rather broad occupational skills than narrow and deep professional skills of tertiary education graduates. In all monitored educational categories employers in the tertiary sector attach the greatest importance to ability to take responsibility, willingness to learn, read and understand the job instructions and solve the problem. In view of the employers in the CR, proficiency in foreign languages represents an attribute of the smallest importance. [5] On the other hand, other research reports about that, "in comparison to other European countries the employers across the Czech business sector were the most likely highlight the importance of sector specific skills“. [24] [25]

3 Most of the studies carried out in the Czech Republic are mainly concerned with the chances and position of the graduates in the labour market or with the economic returns of education or with the assessment of adult competencies (e.g. research project PIAAC) [24] 
As a continuation of our research, we believe it would be interesting to examine the effects of corporate size and fields of specialisation. Considering the difference apparent between the GVI research and our sample of large companies the question arises whether corporate size determines a different pattern of competency requirements. When surveying the competency needs of the corporate sector, requirements arising from the needs of the organisation or from the scope of duties are difficult to separate in the responses. Analyses per field of specialisation would make it possible to separate needs of various 'origin' and to map other effects. The further examination of different preferences in professional and leadership skills could reflect upon the different 'competency management' decisions in the respective fields or indicate different interpretations of the new requirements of the changing economy. The examination of recruitment criteria used in relation to graduates is not sufficient for providing information on competencies to become useful in the future, either. It would be interesting to examine how requirements placed on colleagues change later on, what learning periods they are provided and what new skills they are expected to have several years after their starting their jobs.

The differences between the factors explored in our research and those revealed in the DPR research provide an insight into the respondents' different thinking schemes, indicating that the ways of thinking of fresh graduates and corporate representatives in terms of the respective competency categories may be very different. The differences revealed in our research on requirements towards graduates of technical and economic specialization, may also imply that in the case of different professions, the ways of thinking of participants in terms of general competencies required for these different positions are reflected differently. Competency-based thinking aims at formulating common interpretations, thereby launching a continuous dialogue between players on issues of requirements, learning and compliance with requirements. For researchers at the same time, examining how the respective competencies are arranged in the players' views may be an important starting point for further research, since the differences revealed in the findings of research mapping workplace requirements may too root in different interpretations.

Revealing differences between various countries (e.g. post transformation) may be another interesting way to continue our research and could serve exploring the differences perceived between the requirements or may generate new results with respect to the potentially decisive roles of corporate size or the fields of specialisation.

\section{References}

[1] Amador, L. B., Nicolás Á. L., Vila L. E., Education and Competency Mismatches: Job Satisfaction Consequences for Workers, XVI Jornadas ASEPUMA - IV Encuentro International Rect@VolActas_16Issue1:105

[2] Ádler, J., Stocker, M., Competency-based, Output-oriented Education and 
Ideal Employment, BCE Business Economy Institute for Competitiveness Researches, Budapest, 2012

[3] CEDEFOP, Matching Skills and Jobs in Europe, 2015, http://www.cedefop.europa.eu/en/publications-andresources/publications/8088

[4] Díaz-Fernandez M., López-Cabrales A., Valle-Cabrera R., A Contingent Approach to the Role of Human Capital and Competencies in Firm Strategy. Business Research Quartely, 17, pp. 205-222, 2014

[5] Doležalová, G., The Needs of Employers and the Readiness of Graduates Research in the Tertiary Sector, Praha, 2014, http://www.nuv.cz/uploads/Vzdelavani_a_TP/TER_Potreby_zamestnavatel u_pro_www.pdf

[6] EU 2020 Strategy, http://ec.europa.eu/eu2020

[7] Farkas, A., Comparison of Employers' and Student's Ratings of Importance of Expected Technical Skills, MEB $2008-6^{\text {th }}$ International Conference on Management, Enterprise and Benchmarking, May 30-31, 2008, Budapest

[8] Forgács, K., Kaucsek, Gy., Simon, P., Assessment of the Competent Labour Force with Psychological Test and Script Analysis. Munkaügyi Szemle, 46/9, pp. 12-18, 2002

[9] García-Aracil, A., Rolf van der Velden, Competencies for Young European Higher Education Graduates: Labour Market Mismatches and Their Payoffs. High Educ 55: 219239, 2008

[10] Hajdú, M., Nyírő, Zs., Türei, G., Tóth I. J., Varga A., Data on Higher Education and Employment of Graduates. Facts and Relationships. MKIK GVI, 2015

[11] Halász, G., Előszó. In: Demeter, K. (eds.), Competency: Challenges and Interpretations, National Institute of Education, Budapest, 2006

[12] Kálmán O., Czető K., The Development of the Learning Outcomes Approach in Hungarian Higher Education, XIV. National Education Conference Debrecen, In: Buda A. (ed.), Training and Education - Practice and Science. 8, 2014

[13] Kiss, I., Répáczky, R., New Skills and Work Places: Competence-based Services in Order to Higher Employment, In: Csernovitz, A., Szegedi, E. (eds.), Labour market oriented higher education, TEMPUS, Budapest, 2012

[14] Kiss I., Higher Education Students Life Management, Career-Building Issues, Career Counseling III. 7-8. pp. 6-16, 2011

[15] Kiss, P., Introduction. In: Kiss, P. (eds.), Competency-based Assessment in Higher Education, Educatio, Budapest, 2010

[16] Kiss, P., Demand for Competencies of Graduates and Work Satisfaction, In: Garai, O., Horváth, T, Kiss, L., Szép, L., Veroszta, Zs. (eds.), Graduate 
Survey IV, 2011, Educatio, Budapest, 2011

[17] Lazányi, K., Backgrounds of Skills Mismatches in the Labour Market, Status of Economic Students,. Munkaügyi Szemle 57:(3) pp. 50-62, 2013

[18] McClelland D. C., Testing for Competency Rather than for „Intelligence”. American Psychologist, 28, 1-14, 1973

[19] New Skills for New Jobs, http://ec.europa.eu/social

[20] Polónyi, I., Interest of Employers in Training, In: Polónyi, I., Barizsné, H. E. (eds.), Adult's Training, Corporate Training, Debrecen University, Economic Faculty, 2004

[21] Sági M., Employment Strategies of Career Starter Graduates Pályakezdő diplomások munkába állási stratégiái. In: Garai O., Veroszta Zs., Frissdiplomások 2011, Educatio, 2012

[22] Schomburg, H., The Professional Success of Higher Education Graduates. European Journal of Education. 42 (1), 35-57

[23] Simon, P., Competencies Learnt in Formal and Informal Way, Prepared: „Personal factors of Hungarian economy“ Researches, Budapest, 2006

[24] Straková, J., Vesely, A., V. (eds.), Conditions of Success at the Work and in Life, International Survey of Adult Skills OECD PIAAC, Praha 2013

[25] Employers' Perception of Graduate Employability. Analytical Report. Flash Euro barometer 304 - The Gallup Organization, 2010

[26] Szabó, K., Hámori, B, Information Economy. Akadémia, Budapest, 2006

[27] Szelestey, J., Theoretical Background of Competency Modelling, 2008 http://www.erg.bme.hu/szakkepzes/4felev/SelesteyKompetencia.pdf

[28] Teichler, U., „Employability” or „Professional Relevance”: Changes in Relationships between Higher Education and the World of Work on the Way towards the European Higher Education Area. In: Teicler, U.: Higher Education and the Word of Work. Sense Publishers, Rotterdam, 2009

[29] Tóth P., The Role of Individual Differences in Learning. Acta Polytechnica Hungarica 11:4 pp. 183-197, 2014

[30] Tóth P., Maior E., Pogátsnik M. (ed.), Teacher and Student Competencies in Empirical Researches. Budapest: Ágoston Trefort Centre for Engineering Education, 2015

[31] Tóthné Téglás T., Competence from the View of Employers, Employee and High Education. Business Development in the $21^{\text {st }}$ Century, Budapest, 2016

[32] Winterton, Delamara, What is Competency? Human Resource Development International, Vol. 8, March, No. I, 27-46, 2005

[33] Várhalmi, Z., Graduates in Competitive Sector - 2011, MKIK GVI, Budapest, 2012 